\title{
RESEARCH PAPER \\ COMPARATIVE ANALYSIS OF THE IMPACT OF INDUSTRIAL AND AGRICULTURAL EFFLUENTS ON ONA STREAM IN IBADAN, NIGERIA
}

\author{
K. Ogedengbe ${ }^{1}$ and C. O. Akinbile ${ }^{2}$ \\ ${ }^{I}$ Department of Agricultural \& Environmental Engineering, Faculty of Technology, University of \\ Ibadan, Nigeria. kolaogedengbe@yahoo.com \\ ${ }^{2}$ Department of Agricultural Engineering, Federal University of Technology, P.M.B. 704, Akure, \\ Nigeria.coakinbile@futa.edu.ng,cakinbile@yahoo.com
}

\begin{abstract}
The comparative assessment of industrial and agricultural effluents on surface water qualities of Ona Stream at Oluyole industrial Estate was carried out. This was to identify major pollutants, their effects on water qualities and to ascertain the potential of using the polluted surface water for irrigation purposes. Water samples were collected at pre-determined points along the stream and major parameters were analyzed using standard procedures. Physiochemical and microbiological tests carried out indicated that some parameters gave evidence of pollution due to industrial effluent discharge. The range of values of some of these parameters included dis-

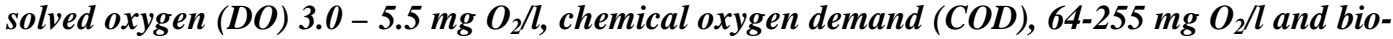
chemical oxygen demand (BOD), 26-70 mg/l. Others were total dissolved solids (TDS), 1285 $2090 \mathrm{mg} / \mathrm{l}$ and Oil and grease, 6.8-3.4 $\mathrm{mg} / \mathrm{l}$. As for agricultural effluents parameters, DO ranged between 1.62 and 5.10mg $\mathrm{O}_{2} / \mathrm{l}, \mathrm{BOD}$ was $26-480 \mathrm{mg} / \mathrm{l}$, COD, 64-1750 $\mathrm{mg} \mathrm{O}_{2} / \mathrm{l}$ and TDS was between 1285 and $2250 \mathrm{mg} / \mathrm{l}$. All the values are above the Federal Environmental Protection Agency (FEPA) maximum allowable limit for effluent discharge into surface water. The statistical analyses carried out showed significant differences in all the physiochemical and heavy metal parameters analyzed at 5\% significance level. Usage of Ona stream for domestic and irrigation purposes was not encouraged due to the health hazards it poses as the presence of contaminants and heavy metal pollution in large quantities confirmed this. Development of clean water technology for water pollution control and application of appropriate polices to compel industries to treat effluent before discharging into the stream are some of the recommendations suggested.
\end{abstract}

Keywords: Effluents, Agriculture, Pollutants, Ona Stream, Ibadan.

\section{INTRODUCTION}

Human health and environmental quality are undergoing degradation by the increasing amount of wastes being produced. Wastes could be complex in nature depending on the sources of generation and its environmental fate once generated. Of all the classification of wastes available, industrial waste is the most occurring source of water pollution (Oyediran, 1997). Sustainable utilization of the World's 


\section{Akinbile and Ogedengbe}

resources and conservation for future generations require prevention and control of pollution and degradation. In the quest for man to increase his food supplies, obtain uncontaminated and clean water to drink and limit damage to his health and to his possessions, the chemical, industrial materials and wastes that would have been used to his advantage have turned out to be the silent conqueror and threat to his existence (NEST, 1991). The inventiveness and curiosity of man have eventually resulted in two complementary factors: the industrial revolution and tremendous population expansion. As long as localization of industry could be an advantage for economic purposes, it also carries along the hazard of environmental pollution with it (Ogedengbe and Akinbile, 2004).

Agriculture, which is the backbone of many economies, has also been adversely affected by upsurge in the indiscriminate dumping and disposal of wastes into land and water courses. The continuous pollution of both surface and underground water sources has reduced the quality and quantity of water needed for general agricultural requirements such as meeting crop water requirements during insufficient rainfall (Sangodoyin, 1991). The enormity of major global environmental problems facing mankind today and the next century is derived from the stratospheric ozone layer depletion, climate change and global warming. Others are acid rain, loss of biological diversity, air water pollution. The rest include trans-boundary movement of toxic and hazardous wastes which are caused directly or indirectly by industrialization (Nubi, 2002).

In the developed world, domestic sewage, industrial and agricultural wastes are treated at sewage central works to reduce their toxicity and discharged into rivers and stream. In Nigeria, this is not so. Prior to population explosion, agricultural and industrial activities have been practiced on a very small scale (Akinbile, 2006). The waste generated has been disposed using simple techniques. However, due to in- creasing rapid and haphazard urbanization, technological exploits, large scale farming has affected the quality of surface and underground water and their ability to support life (Ongley, 1998).

The rapid increase in domestic, agricultural, municipal and industrial wastes in developing world under the combined effects of increasing population, industries and urbanization have been reported by various researchers viz: Sangodoyin, (1991), Osibajo (2001), Nubi, (2002), NEST (1991), Ongley (1998), Ogedengbe and Akinbile (2004). They all remarked that developing countries such as Nigeria suffer from problems arising from effluent discharge into river courses and agricultural pollution in surface runoff and ground water sources. In the light of indiscriminate dumping and release of pollutants and effluents into the environment, it is therefore necessary to identify and compare the impact of industrial and agricultural effluents on surface water quality.

The objective of this study therefore was to access and compare the impact of selected industrial and agricultural effluents on Ona stream. To conduct qualitative analyses of effluents discharged into the stream, physiochemical, microbiological and heavy metal tests were carried out. Another objective was to identify common pollutants, their effects on the stream and also examine the possibility of using the stream for irrigation purposes. This was to ascertain the suitability or otherwise of the stream for domestic uses, determine the required degree of treatment before use and to also consider the issue of wastewater re-cycling in the wake of growing water shortage occasioned by emerging trend of climate change.

\section{STUDY AREA AND METHODOLOGY Description of the Study Area}

Oluyole Industrial Estate is located in Ibadan South West local government area of Oyo State. The State is one of the six states located within the south western zone of Nigeria (Fig. 1). Located on latitude $7^{0} 22^{1} \mathrm{~N}$ and longitude $3^{0}$ 
$58^{1} \mathrm{E}$, Ibadan is a densely populated city in $\mathrm{Ni}$ geria with a population figure of 874,039 (NPC, 2006 provisional census). The city has an annual rainfall ranging between $1260 \mathrm{~mm}$ and $1460 \mathrm{~mm}$ and temperature ranges between $24.7^{\circ} \mathrm{C}$ and $29.1^{\circ} \mathrm{C}$. It has two distinct seasons; rainy season from April to October and dry season from November to March. Ona River is a major stream in Ibadan flowing through the entire length of the city from north to south, though receiving water from other smaller rivers within the city. The choice of the stream was informed by the fact that majority of industries located in Ibadan are cited very close to the stream which serves as a means of disposing off wastes and effluents from the neighbouring industries. Some major industries in the estate include, Vital Foods, Yale Foods, Seven Up Bottling Company, Interpak Packaging and ZarTech Agricultural limited. This practice has rendered the stream unsuitable for domestic uses (Ogedengbe and Akinbile, 2004).

\section{Methodology}

Ona Stream was divided into three zones for sampling namely; the upstream portion, point of discharge and down stream portion. Samples were collected at the upstream portion (US) at Aba Alamu / Ago tailor area for both industrial and agricultural effluents. Along Oluyole extension (DS1), a set of samples were collected at the point of discharge of industrial effluents. Another set of samples were collected at Ogun / Oshun river basin area (DS2) for both industrial and agricultural effluents at the down stream portion. At Ago Igbira / Odo Ona Elewe area (DS3) samples for analysis were collected at the point of leaving the estate (Fig 1).

Chemical and bacteriological analyses of the samples were carried out at the water laboratory unit of the International Institute of Tropical Agriculture (IITA) Ibadan, Nigeria. Chemical analyses carried out included the $\mathrm{pH}$, using a $\mathrm{pH}$ meter, total alkalinity which was done volumetrically by titration and temperature was measured with the aid of thermometer. Others are Dissolved Oxygen (DO), which was measured with the aid of a DO analyzer, Chemical Oxygen Demand (COD), Biochemical Oxygen Demand (BOD) and Total Hardness (TH). The rest include Chloride, Sulphate, Phosphate, Nitrate, Calcium, Magnesium, Total Solids (TS), Total Suspended Solids (TSS), Total Dissolved Solids (TDS), Oil and grease contents. BOD analysis was done when samples were incubated for 5 days at $20^{\circ} \mathrm{C}$. It was aerated with a diffused air to alter the dissolved gas content to near saturation. After five days, amount of DO remaining in incubated samples were determined and the five day BOD calculated. The quantity and presence of heavy metals such as nickel, chromium, zinc, lead, copper and cadmium were also tested for using atomic absorption spectrophotometry. The presence and total count of coliform organisms were detected by bacteriological assay. Measurements using standardized solutions were carried out to determine presence of chlorides, suphates, phosphates, nitrates and nitrites in the samples. All these were done using standard procedures as spelt out in the Association of Analytical chemists (AOAC) (1990). Statistical analysis was carried out using test procedure at $5 \%$ significance level to determine their variations .

\section{RESULTS AND DISCUSSION}

Impact of Agricultural and Industrial effluent on Physical and Chemical parameters of Ona Stream.

The levels of the physical and chemical parameters analyzed for industrial and agricultural effluents in Ona stream were as shown in Tables 1 and 2 respectively. The $\mathrm{pH}$ values ranged between 7.5 and 8.5 for both agricultural and industrial effluents. The values obtained are well within FAO (1995) maximum permissible limits for discharge and water quality for irrigation.

Alkalinity levels for the agricultural effluent increased from upstream value of $175 \mathrm{mg} / 1$ (Table1) to $214 \mathrm{mg} / 1$ at point of discharge (POD) which is the upstream and downstream. 


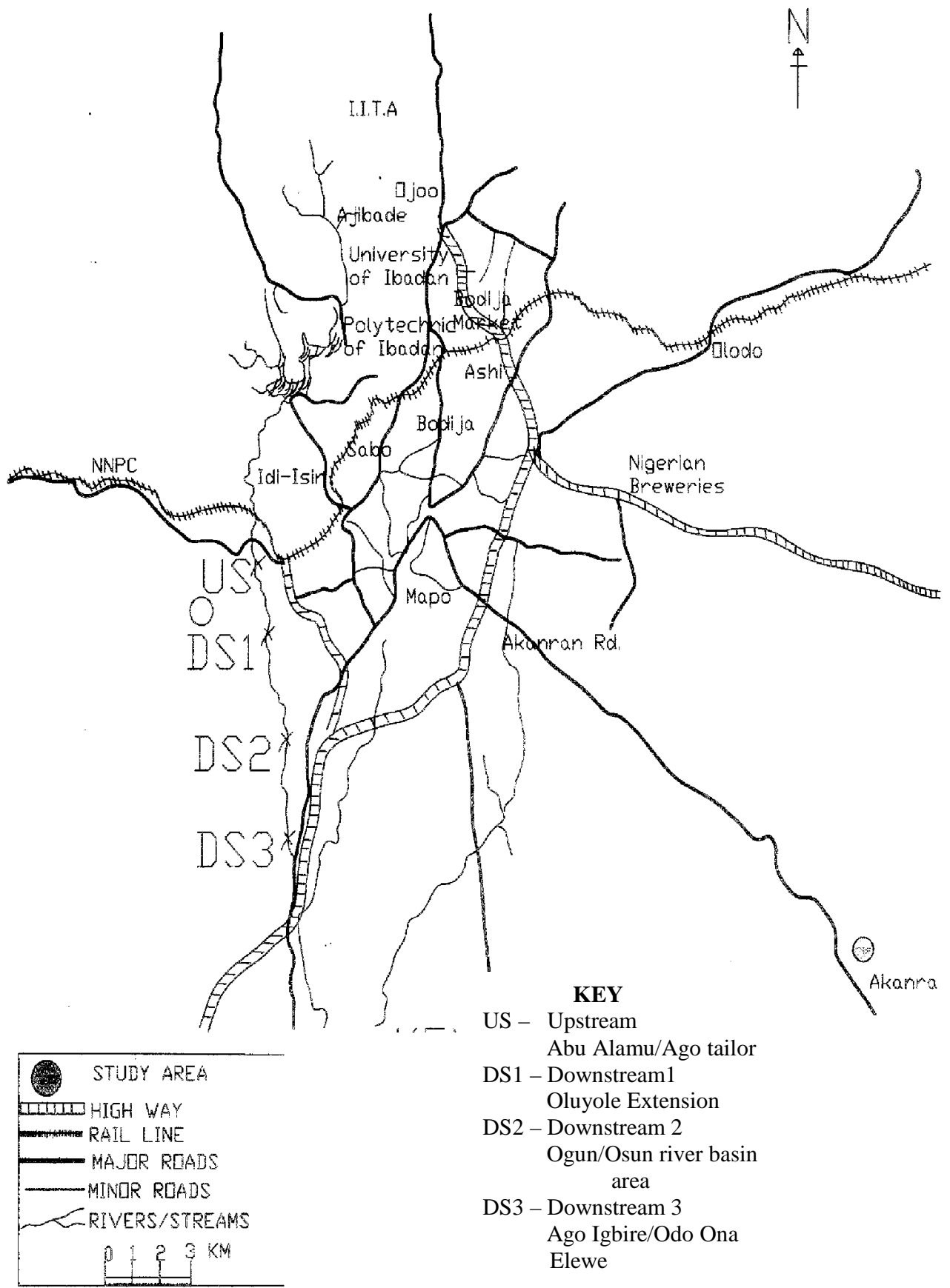

Fig. 1 : Map of Ibadan City showing Ona Stream and the points of water selection for analyses 
Table 1: Impact of industrial effluent discharge of physic-chemical parameters of Ona Stream

\begin{tabular}{|c|c|c|c|c|c|c|c|c|c|c|}
\hline Parameters & US1 & US2 & USMV & POD & DS1 & DS2 & DS3 & Range & DSMV & $\begin{array}{l}\text { Highest } \\
\text { desirable }\end{array}$ \\
\hline Temp $\left({ }^{0} \mathrm{C}\right)$ & 28.2 & 29.8 & 29.0 & 31.5 & 30.6 & 31 & 32 & $\begin{array}{l}28.2- \\
32.8\end{array}$ & 31.20 & 45 \\
\hline $\mathrm{pH}$ & 8.5 & 7.5 & 8.0 & 8.0 & 7.6 & 7.6 & 7.8 & $7.5-8.5$ & 7.77 & $6.5-8.5$ \\
\hline DO & 5.5 & 4.7 & 5.10 & 3.7 & 3.8 & 4.9 & 3.5 & $3.5-55$ & 4.07 & \\
\hline COD & 64 & 68 & 66.0 & 255 & 235 & 125 & 190 & $64-255$ & 183.3 & 200 \\
\hline BOD & 26 & 30 & 28.0 & 70 & 58 & 44.5 & 51.2 & $26-70$ & 51.2 & 250 \\
\hline $\begin{array}{l}\mathrm{TS} \\
\left(\mathrm{mgCaCO}_{3} / \mathrm{l}\right)\end{array}$ & 110 & 115 & 112.5 & 120 & 112 & 104 & 12 & $\begin{array}{l}104- \\
132\end{array}$ & 47.9 & $0.3-10$ \\
\hline $\begin{array}{l}\text { TA } \\
\left(\mathrm{mgCaCO}_{3} / \mathrm{l}\right)\end{array}$ & 190 & 175 & 182.5 & 230 & 200 & 185 & 154.0 & $\begin{array}{l}175- \\
230\end{array}$ & 179.67 & $50-100$ \\
\hline Chloride & 42.8 & 43.4 & 43.1 & 46.8 & 44.0 & 40.5 & 48 & $\begin{array}{l}40.5- \\
48\end{array}$ & 44.17 & 250 \\
\hline Sulphate & 23.8 & 20.5 & 22.15 & 29.3 & 25.4 & 26.3 & 19.6 & $\begin{array}{l}19.6- \\
29.3\end{array}$ & 37.77 & 150 \\
\hline Phosphate & 0.66 & 0.42 & 0.54 & 1.15 & 1.09 & 0.92 & 1.56 & $\begin{array}{l}0.42- \\
1.56\end{array}$ & 1.19 & $0.01-0.1$ \\
\hline Nitrate & 1.09 & 1.15 & 1.12 & 1.54 & 1.45 & 1.48 & 1.48 & $\begin{array}{l}1.08- \\
1.48\end{array}$ & 1.47 & 45 \\
\hline Calcium & 40.1 & 35.5 & 37.8 & 42.5 & 42.0 & 40.5 & 41.2 & $\begin{array}{l}35.5- \\
42.5\end{array}$ & 41.23 & 75 \\
\hline Magnesium & 18.5 & 19.3 & 18.9 & 20 & 16.5 & 12.2 & 19.8 & $\begin{array}{l}12.2- \\
19.8\end{array}$ & 16.17 & 30 \\
\hline TS & 1314 & 1704 & 1509 & 1953 & 1946 & 1890 & 2126 & $\begin{array}{l}1314- \\
2126\end{array}$ & 1993.3 & 1500 \\
\hline TSS & 29 & 28 & 28.5 & 33 & 36 & 29 & 36 & $28-36$ & 33.67 & 10 \\
\hline TDS & 1285 & 1676 & 1480.5 & 1920 & 1928 & 1861 & 2090 & $\begin{array}{l}1285- \\
2090\end{array}$ & 1959.7 & 500 \\
\hline Oil \& grease & 6.8 & 8.0 & 7.4 & 17.5 & 17.1 & 10.5 & 33.4 & $\begin{array}{l}6.8- \\
33.4\end{array}$ & 20.33 & $10-20$ \\
\hline $\begin{array}{l}\text { *Distance } \\
(\mathrm{m})\end{array}$ & & -80 & -25 & & 0 & 60 & 2500 & 5000 & & \\
\hline
\end{tabular}

$\mathrm{pH}$ is dimensionless $\quad$ unless otherwise stated all units are in $\mathrm{mg} / \mathrm{L}$

Legend:

US - Upstream USMV - Upstream mean value

$P O D$ - Point of discharge DS - Downstream

DSMV- Downstream mean value * Distance measured from point of discharge 


\section{Akinbile and Ogedengbe}

(DSI) (Table 2), while it increased to $230 \mathrm{mg} / 1$ for the industrial effluent at POD (Table 1). These by far exceeded the FAO (1995) stipulated limit of $200 \mathrm{mg} / \mathrm{l}$ and may be due to untreated effluents discharged directly into the stream. High alkalinity levels are usually associated with increase in presence of bicarbonates and carbonates from effluents and leachate. However, there was evidence of self purification of the stream at DS3 as the alkalinity levels reduced to $154 \mathrm{mg} / 1$ (Table 1) and $115 \mathrm{mg} / 1$ (Table 2) and may be due to the travelled distance between two sampling points (DS2 and DS 3 by the stream. Exposure to atmosphere and movement away from polluting sources may have contributed to the noticeable reduction in concentration levels of alkalinity. This was well within FEPA (1991) limit and useful for land application and irrigation use. Temperature increased from US to POD from 29 to $31^{\circ} \mathrm{C}$ and further increased at DS3 to $32^{\circ} \mathrm{C}$ in industrial effluents (Table 1) but the temperature trend from POD to DS3 was slightly lower from 28.7 to $29.5^{\circ} \mathrm{C}$ (Table 2) in agricultural effluent. Akinbile (2006) reported that noticeable high temperature confirmed the presence of some biological species and their rates of activity in such samples. Temperature had an effect on most chemical reactions that occur in natural systems and the amount of DO gases in it. High concentration of Sulphate and Phosphate when compared with FAO (1995) limit is indicative of presence of the agricultural activities such as poultry in the study area.

The values of the dissolved oxygen (DO) in the upstream (US) region of the stream was used to classify the stream as a class III stream which means it is slightly polluted (Table 3 ). This rendered the stream lifeless at this point of downstream (DS1). The DO values at DS3 increased to $3.5 \mathrm{mgO}_{2} / 1$ (Table 1) and $3.9 \mathrm{mgO}_{2} / 1$ (Table 2) for both the manufacturing industry and the poultry farm located at Odo Ona Elewe near the stream respectively. Lower DO values are often associated with increase in TSS, TDS, BOD and domestic pollutions. Consequently, there is a decrease in fish and other aquatic life forms downstream with the stream having foul smell.

The contributions of nitrate at the upstream were considerably low when compared with the point of discharge for both effluents. The effluent from the poultry has higher concentration of nitrate at $165.24 \mathrm{mg} / \mathrm{l}$ at POD (Table 2) compared with $1.54 \mathrm{mg} / \mathrm{l}$ of nitrate (Table 1 ) from the manufacturing industry. This was due to discharge of untreated pen washings/slaughter house effluents into the stream. There was evidence of self purification at the downstream. Water that is contaminated with nitrate proves harmful especially to infants causing methaemoglobinaemia otherwise called infantile cyanosis or blue baby syndrome if consumed (Akinbile, 2006). It is a serious blood condition in which the nitrates are absorbed into the blood stream and converting oxygencarrying hemoglobin into methaemoglobin. The level of calcium and magnesium in the samples was relatively stable and within acceptable limit. The calcium and magnesium values express the total hardness of the effluent and help to classify the effluent as either hard or soft. The sample in this case is soft. The sample is suitable for irrigation and also for soil/plant amelioration.

The total dissolved solids (TDS) and the total suspended solids (TSS) from the poultry effluents far exceeded the FEPA (1991) limit of $2000 \mathrm{mg} / 1$ and $50 \mathrm{mg} / \mathrm{l}$ respectively at the POD and DS1. This was as a result of organic waste discharged directly into the stream. The parameters were also found to be inconsistent for the manufacturing industry discharged into Ona stream. It ranged between $1285 \mathrm{mg} / 1$ - 2090 $\mathrm{mg} / 1$ for TDS and $1314 \mathrm{mg} / 1$ - $2126 \mathrm{mg} / 1$ TSS. The effect of these high values would bring about direct bearing on the salinity of the soil if used for irrigation. Salinity of the soil to some extent depends on the salinity of irrigation water and this will adversely affect crop yield, plant growth and quality of products (Akinbile, 2006). 
Comparative analysis of the impact... 39

Table 2 : Impact of Agricultural effluent on physic-chemical parameters of Ona Stream

\begin{tabular}{|c|c|c|c|c|c|c|c|c|c|c|}
\hline Parameters & US1 & US2 & USMV & POD & DS1 & DS2 & DS3 & Range & DSMV & $\begin{array}{l}\text { Guide- } \\
\text { line } \\
\text { value }\end{array}$ \\
\hline Temp $\left({ }^{0} \mathrm{C}\right)$ & 28.2 & 29.8 & 29.00 & 30.8 & 28.70 & 29.0 & 29.50 & $\begin{array}{l}28.2- \\
30.8\end{array}$ & 29.07 & 45 \\
\hline $\mathrm{pH}$ & 8.5 & 7.5 & 8.0 & 6.3 & 7.8 & 7.5 & 7.5 & $\begin{array}{l}7.5- \\
8.5\end{array}$ & 7.60 & $6.5-8.5$ \\
\hline DO & 5.5 & 4.7 & 5.10 & 1.62 & 2.0 & 4.3 & 3.9 & $\begin{array}{l}1.62- \\
5.10\end{array}$ & 3.40 & \\
\hline COD & 64 & 68 & 66 & 1750 & 1200 & 87 & 110 & $\begin{array}{l}64- \\
1750\end{array}$ & 465.67 & 200 \\
\hline BOD & 26 & 30 & 28 & 480 & 250 & 31 & 42 & $\begin{array}{l}26- \\
480\end{array}$ & 107.67 & 250 \\
\hline $\begin{array}{l}\mathrm{TS} \\
\left(\mathrm{mgCaCO}_{3} /\right. \\
\text { 1) }\end{array}$ & 110 & 115 & 112.50 & 223 & 219 & 211 & 193 & $\begin{array}{l}104- \\
223\end{array}$ & 207.67 & $0.3-10$ \\
\hline $\begin{array}{l}\mathrm{TA} \\
\left(\mathrm{mgCaCO}_{3} /\right. \\
\text { 1) }\end{array}$ & 190 & 175 & 182.50 & 214 & 214 & 185 & 115 & $\begin{array}{l}175- \\
214\end{array}$ & 171.33 & $50-100$ \\
\hline Chloride & 42.8 & 43.4 & 43.10 & 130 & 133 & 132 & 121 & $\begin{array}{l}40.5- \\
133\end{array}$ & 128.67 & 250 \\
\hline Sulphate & 23.8 & 20.5 & 22.15 & 62 & 50 & 48 & 23.5 & $\begin{array}{l}19.6- \\
62\end{array}$ & 40.50 & 150 \\
\hline Phosphate & 0.66 & 0.42 & 0.54 & 3.9 & 2.28 & 2.01 & 1.13 & $\begin{array}{l}0.42- \\
3.9\end{array}$ & 1.81 & $0.01-0.1$ \\
\hline Nitrate & 1.09 & 1.15 & 1.12 & 165.24 & 112.5 & 45 & 18 & $\begin{array}{l}108- \\
165.24\end{array}$ & 58.50 & 45 \\
\hline Calcium & 40.1 & 35.5 & 37.8 & 159.80 & 140 & 139.4 & 101.7 & $\begin{array}{l}35.5- \\
159.8\end{array}$ & 127.03 & 75 \\
\hline Magnesium & 18.5 & 19.3 & 18.9 & 146.30 & 138.2 & 133.5 & 105.5 & $\begin{array}{l}12.2- \\
146.30\end{array}$ & 125.73 & 30 \\
\hline TS & 1314 & 1704 & 1509 & 12303 & 2050 & 1691 & 2010 & $\begin{array}{l}1314- \\
2303\end{array}$ & 1917 & 1500 \\
\hline TSS & 29 & 28 & 28.5 & 53 & 50 & 21 & 38 & $\begin{array}{l}28- \\
533\end{array}$ & 36.33 & 10 \\
\hline TDS & 1285 & 1676 & 1480.5 & 2250 & 2000 & 1670 & 1972 & $\begin{array}{l}1285- \\
2250\end{array}$ & 1880.67 & 500 \\
\hline Oil \& grease & 6.8 & 8.0 & 7.40 & 7.10 & 6.8 & 6.8 & 4.3 & $\begin{array}{l}4.3- \\
7.4\end{array}$ & 5.96 & $10-20$ \\
\hline $\begin{array}{l}\text { *Distance } \\
(\mathrm{m})\end{array}$ & & -80 & -25 & & 0 & 60 & 2500 & 5000 & & \\
\hline
\end{tabular}

pH is dimensionless

unless otherwise stated all units are in $\mathrm{mg} / \mathrm{L}$ 
Table 3 : Parameters (Indicative of gross organic pollution) used in the classification of surface water quality

\begin{tabular}{lllllll}
\hline Parameters & Class I & Class II & Class III & Class IV & \multicolumn{2}{c}{ Class V } \\
\hline $\mathrm{pH}$ & $6.5-8.0$ & $6.5-8.4$ & $5.0-9.0$ & $3.9-10.1$ & $3.9-10.1$ & $5.5-9.0$ \\
$\mathrm{DO}$ & 7.8 & 6.2 & 4.6 & 1.8 & 1.8 & \\
$\mathrm{BOD}$ & 1.5 & 3.0 & 6.0 & 12.0 & 12.0 & \\
$\mathrm{NH}_{3}$ & 0.1 & 0.3 & 0.9 & 2.7 & 2.7 & $0.01-0.1$ \\
$\mathrm{COD}$ & 10 & 20 & 40 & 80 & 80 & \\
$\mathrm{SS}\left(\mathrm{mgCaCO}_{3} / \mathrm{l}\right)$ & 20 & 40 & 100 & 278 & 278 & \\
\hline
\end{tabular}

pH is dimensionless $\quad$ unless otherwise stated all units are in $\mathrm{mg} / \mathrm{L}$

Source: Prat (1971) As quoted by Osibanjo, 2001

Class I - Excellent Quality

Class II - Acceptable Quality

Class III - Slightly polluted

Class IV-Polluted

Class V-Heavily polluted.

The high values of oil and in grease are indicative of contributions from the manufacturing industrial effluent discharge and oil leakages noticed at POD and DS3 (Table 1). The DS3 value was higher (33.4); this may be due to location of a mechanic workshop nearby and the usage of Ona stream as a cheap source for automobile washing services. It ranged between $6.8 \mathrm{mg} / \mathrm{l}-33.4 \mathrm{mg} / 1$ and does not conform to FAO (1995) standard of $10 \mathrm{mg} / 1$. However, the values are within limit for the poultry effluent. It ranges between $4.3 \mathrm{mg} / 1-7.4 \mathrm{mg} / 1$. The variation of oil and grease for both effluents along the course of Ona stream is shown in Fig. 10. In case of heavy pollution, prevention of natural aeration of the stream leading to death of aquatic life is a normal occurrence. The maximum phosphate level in the samples was $1.56 \mathrm{mg} / 1$ for the manufacturing industry (Table 1). This is in conformity with FAO (1995). Phosphate helps in the formation of nuclei proteins and co-enzymes for plants hence its suitability for irrigation in a phos- phate deficient soil (Sangodoyin, 1991). The BOD upstream value of $26 \mathrm{mgO}_{2} / 1$ was further increased at point of discharge to $70 \mathrm{mgO}_{2} / 1$ (Table 1) and $480 \mathrm{mgO}_{2} / 1$ (Table 2) for the manufacturing industry effluent and the poultry effluent respectively. This was due to increase in TS, TSS, TDS and COD. Increase in BOD of the poultry effluent at POD to $480 \mathrm{mgO}_{2} / \mathrm{l}$ was also due to the nature of organic pollutions produced in the farm (Nubi, 2002).

\section{Presence of Heavy Metal in water/effluent samples}

The analytical concentrations of the heavy metals in the effluents and water samples are listed on Tables 4, 5 and 6 respectively. The heavy metals contained mostly in the poultry effluent samples are very well below FAO (1995) and FEPA (1991) maximum concentration limits for disposal. However, the industrial effluent was slightly significant in concentration especiially copper and leads at POD and DS3 (Table $6)$. This was also due to the nature of raw mate- 
rials used in the industry.

Impact of Agro-industrial Effluent discharge on Microbiological parameters of Ona stream.

The results of the microbiological test of both effluents and the water samples are as reported in Table 7 and 8 respectively. It was generally observed that there was evidence of faecal and bacteria contamination of the effluent and water samples along the river course. The total coliform counts for the effluent was $6.0 \times 10^{3}$ and $2.5 \times 10^{3} \mathrm{cfu} / \mathrm{ml}$ for both the agricultural and industrial effluent respectively (Table 5). These values are well above FEPA (1991) limit.

From the comparative analysis of the results of the physico - chemical parameters using T-test and ANOVA, chloride, calcium , magnesium and total measured have a significant difference At 0.05 level of confidence. This was attributed to introduction of some other sources of pollution at the downstream other than the agro industrial effluents.

\section{CONCLUSION}

A comparative analysis of the impact of industrial and agricultural effluents discharged into Ona Stream in Ibadan, Nigeria was carried out. Out of the two effluents in terms of physical, chemical and microbiological parameters monitored, the agricultural effluent was considered to have higher pollution effects. A great evidence of organic pollution observed in the stream was predominantly from slaughterhouse effluents and domestic wastes. Low values of DO and high values of COD, BOD TSS and TDS were observed. In terms of presence of heavy metal content, Ona stream was found to be moderately polluted from the industrial effluents than that of agricultural effluent. It was concluded that surface runoffs, leakages, vehicular emissions and untreated effluent discharged by some industries may have contributed to the level of metal contents in the stream. The impact of faceal and bacteria contamination on the stream was observed throughout the sampling points and its pollution concentration was quite high.

Table 4: Impact of Agricultural Effluent discharge on Heavy metals Ona Stream

\begin{tabular}{|c|c|c|c|c|c|c|c|c|c|c|}
\hline $\begin{array}{l}\text { Parame- } \\
\text { ters }\end{array}$ & US1 & US2 & USMV & POD & DS1 & DS2 & DS3 & Range & DSMV & $\begin{array}{l}\text { Guide- } \\
\text { line } \\
\text { value }\end{array}$ \\
\hline Nickel & 0.005 & 0.015 & 0.012 & 0.024 & 0.017 & 0.003 & ND & $\begin{array}{l}\text { ND- } \\
0.024\end{array}$ & 0.01 & 3 \\
\hline Chromium & ND & ND & - & 0.004 & 0.002 & ND & 0.003 & $\begin{array}{l}\text { ND- } \\
0.004\end{array}$ & 0.0025 & $0.1-1.0$ \\
\hline Zinc & 0.30 & 0.34 & 0.32 & 0.42 & 0.4 & 0.4 & 0.2 & $\begin{array}{l}0.2- \\
0.4\end{array}$ & 0.33 & 5 \\
\hline Lead & ND & $<0.001$ & - & 0.025 & $<0.001$ & $<0.001$ & 0.532 & $\begin{array}{l}\text { ND- } \\
0.532\end{array}$ & 0.27 & 0.1 \\
\hline Copper & 0.005 & 0.005 & 0.005 & 0.91 & 0.12 & 0.12 & 0.64 & $\begin{array}{l}\text { ND- } \\
0.91\end{array}$ & 0.36 & 1 \\
\hline Cadmium & ND & ND & - & 0.002 & $<0.001$ & $<0.001$ & 0.021 & $\begin{array}{l}\text { ND- } \\
0.021\end{array}$ & 0.008 & 1 \\
\hline
\end{tabular}

Except otherwise stated, all units are in $\mathrm{g} / \mathrm{mL}$

Legend: $N D$ - Non detectable, Heavy metals $(\mu \mathrm{g} / \mathrm{ml})$ 
Table 5: Impact of Agro Industrial effluent discharge on Ona Stream

\begin{tabular}{|c|c|c|c|}
\hline Parameters & Agricultural effluent & Industrial effluent & FAO Values \\
\hline Temp $\left({ }^{0} \mathrm{C}\right)$ & 31.5 & 32 & 25 \\
\hline $\mathrm{pH}$ & 6.9 & 6.9 & $6.5-8.5$ \\
\hline DO & 1.4 & 1.6 & 2.0 \\
\hline COD & 1830 & 380 & 350 \\
\hline BOD & 550 & 100 & 10 \\
\hline $\mathrm{TH}\left(\mathrm{mgCaCO}_{3} / \mathrm{l}\right)$ & 240 & 170 & 350 \\
\hline $\mathrm{TA}\left(\mathrm{mgCaCO}_{3} / \mathrm{l}\right)$ & 225 & 255 & 200 \\
\hline Chloride & 160 & 54.5 & 100 \\
\hline Sulphate & 84 & 34.4 & 20 \\
\hline Phosphate & 4.5 & 1.94 & 3.0 \\
\hline Nitrate & 262.4 & 1.91 & 10 \\
\hline Calcium & 166.0 & 75.8 & 20 \\
\hline Magnesium & 150 & 23 & 20 \\
\hline TS & 2820 & 2035 & 2000 \\
\hline TSS & 70 & 45 & 40 \\
\hline TDS & 2750 & 1990 & 2000 \\
\hline Oil \& grease & 9.7 & 19.2 & 10 \\
\hline Nickel (g/ml) & ND & 0.059 & ND \\
\hline Chromium (g/ml) & 0.004 & 0.008 & 0.01 \\
\hline Zinc (g/ml) & 0.025 & 0.581 & 0.01 \\
\hline Lead $(\mathrm{g} / \mathrm{ml})$ & 0.025 & 0.035 & 0.005 \\
\hline Copper(g/ml) & 0.008 & 1.50 & 1.0 \\
\hline Cadmium (g/ml) & 0.004 & 0.004 & 0.001 \\
\hline $\begin{array}{l}\text { Total coliform count } \\
\text { (cfu) }\end{array}$ & $6.0 \times 10^{3}$ & $2.5 \times 10^{3}$ & $1 \mathrm{in} 100 \mathrm{ml}$ \\
\hline Total plate count (cfu) & $8.7 \times 10^{3}$ & $4.0 \times 10^{3}$ & - \\
\hline
\end{tabular}


Table 6 : Impact of industrial effluent discharge on heavy metal contents of Ona Stream

\begin{tabular}{|c|c|c|c|c|c|c|c|c|}
\hline Parameters & USMV & POD & DS1 & DS2 & DS3 & Range & DSMV & $\begin{array}{l}\text { Guideline } \\
\text { value }\end{array}$ \\
\hline Nickel & 0.012 & ND & ND & ND & ND & $\mathrm{DN}$ & ND & 3 \\
\hline Chromium & - & 0.005 & ND & 0.003 & 0.001 & $\begin{array}{l}\text { ND- } \\
0.005\end{array}$ & 0.002 & $0.1-2.0$ \\
\hline Zinc & 0.32 & 0.002 & $<0.001$ & ND & ND & $\begin{array}{l}\text { ND- } \\
0.002\end{array}$ & - & 5 \\
\hline Lead & - & 0.013 & $<0.001$ & ND & ND & $\begin{array}{l}\text { ND- } \\
0.013\end{array}$ & - & 0.1 \\
\hline Copper & 0.005 & 0.026 & 0.002 & 0.001 & $<0.001$ & $\begin{array}{l}<0.001 \\
-0.026\end{array}$ & 0.002 & 3 \\
\hline Cadmium & - & 0.002 & $<0.001$ & $<0.001$ & ND & $\begin{array}{l}\text { ND- } \\
0.002\end{array}$ & - & 1 \\
\hline
\end{tabular}

Except otherwise stated, all units are in $\mathrm{g} / \mathrm{mL}$

Table 7: Impact of Agricultural effluents discharge on microbiological parameters of Ona Stream

\begin{tabular}{llllll}
\hline & Parameters & US & Effluent & POD & DS \\
\hline a & $\begin{array}{l}\text { Total plate count at } 35^{0} \mathrm{C} \text { for } 24 \\
\text { hours }\end{array}$ & $9.6 \times 10^{2}$ & $8.7 \times 10^{3}$ & $6.3 \times 10^{3}$ & $5.2 \times 10^{3}$ \\
b & $\begin{array}{l}\text { Total coliform count at } 35^{\circ} \mathrm{C} \text { for } 24 \\
\text { hours }\end{array}$ & $4.3 \times 10^{2}$ & $6.0 \times 10^{3}$ & $4.8 \times 10^{3}$ & $3.7 \times 10^{3}$ \\
c & Distance $(\mathrm{m})$ & 80 & & 0 & 2500 \\
\hline
\end{tabular}

All units in cfu/m (Colony forming unit)

The feasible impact of agro-industrial effluent on water quality showed that the industries within Oluyole Estate rarely treat their effluents before discharging them into the Ona stream. This is dangerous to both human and aquatic life as evident in DO reduction. Furthermore, from the test carried out, usage of the stream for agricultural purposes such as livestock and irrigation will have adverse negative effects on plants, crops and animals. Also, evidence of coliform pollutant in the stream had rendered it unsuitable for domestic purposes especially for 
Table 8: Impact of industrial effluents discharge on Microbiological parameters of Ona Stream

\begin{tabular}{|c|c|c|c|c|c|}
\hline & Parameters & US & Effluent & POD & DS \\
\hline a & Total plate count at $35^{\circ} \mathrm{C}$ for 24 hours & $9.6 \times 10^{2}$ & $4.0 \times 10^{3}$ & $2.8 \times 10^{3}$ & $3.8 \times 10^{3}$ \\
\hline $\mathrm{b}$ & $\begin{array}{l}\text { Total coliform count at } 35^{\circ} \mathrm{C} \text { for } 24 \\
\text { hours }\end{array}$ & $4.3 \times 10^{2}$ & $2.5 \times 10^{3}$ & $1.8 \times 10^{3}$ & $2.6 \times 10^{3}$ \\
\hline $\mathrm{c}$ & Distance (m) & 80 & & 0 & 2500 \\
\hline
\end{tabular}

All units in cfu/ml (Colony forming unit)

areas around Ago-Igbira community. This was due to high level of contamination occasioned by human feaces being passed into the stream in this area. Sound management of environmental-friendly effluent is among the issues that are of major concern in maintaining the quality of earth natural resources for healthy sustainable development.

The following are the recommendations from this study;

Periodic assessment, data collation and analysis and systematic reporting of environmental pollution to appropriate agencies are recommended. The need to re-inform industries using central drainage systems channeled into Ona stream of proper treatment of effluents while conforming to minimum safety standards before final discharge becomes inevitable. Also, mathematical models should be generated for predicting the level of pollution at different portions on the stream. These models can be formulated after repeated sampling and analysis of water and effluents. The residents of these areas should be educated on various ways of water treatment before use while government should provide alternate potable water for their domestic uses.

Furthermore, more studies in the field of industrial and domestic waste reuse are suggested for different range of crops with different soil and crop management techniques. This is to determine their effects on crop yield and suitability for use a source of irrigation water.

Finally, development and application of clean technology; which involves treatment of agro industrial discharges, municipal waste water for safe reuse in agriculture should be encouraged. This is to be used for waste treatment recycling and for water pollution control considering traditional and indigenous practices.

\section{REFERENCES}

Akinbile, C.O. (2006). Hawked Water Quality and its Health Implications in Akure, Nigeria, Botswana Journal of Technology 15(2) : 70-75

Association of Official Analytical Chemists (AOAC) (1990). Official Methods of Analysis, $15^{\text {th }}$ Edition, Arligton, Virginia.

Food and Agriculture Organization (FAO) (1995). Environmental Impact Assessment of Irrigation and Drainage Projects, FAO, Rome.

Federal Protection Agency (FEPA) (1991). Guidelines and Standards for Environmental Pollution Control in Nigeria.

National Population Commission (NPC) Abuja. 
(2006). Nigeria’s national Census.

NEST (1991). Nigeria Threatened Environment. A National Profile, NEST Publication, Ibadan:76-88.

Nubi, O. A. (2002). Pollution Assessment of the impact of Industrial effluent and Dumpsite Leachate on the Qualities of Surface Water, Ground water and sediments of Tiro receiving stream in Ibadan, Oyo State. Unpublished M.Sc project, Dept of Chemistry, University of Ibadan, Nigeria, :159

Ogedengbe, K. and Akinbile, C. O. (2004). Impact of Industrial Pollutants on Quality of Ground and Surface waters at Oluyole Industrial Estate, Ibadan, Nigeria, Nigerian Journal of Technological Development 4 ( 2) :139-144

Ongley, E. D. (1998). Modernization of Water Quality Programs in Developing Countries,
Issues of relevancy and cost of Efficiency, Water Quality International, 7-42.

Osibanjo, O. (2001). Overview of Hazardous waste according to the BA'SEL Convection Seminar Dissertation of Awareness Raising on Hazardous wastes Management" UNIDO/FAO/SBC/FMENO, Lagos, Nigeria, : 22-29

Oyediran, A. B. O. O. (1997). A keynote Address on Waste Generation and Disposal in Nigeria in "Perspectives in Environmental Management" in NEST Annual Workshops 1991 to 1995 (D. Okali, K.O Ologe and U.M Igbozurike eds.), NEST-Desktop Publications, Ibadan, Nigeria, 95-100

Sangodoyin, A. Y. (1991). Ground Water and Surface Water Pollution by Open Refuse dump in Ibadan, Nigeria, Discovery and Innovations, 3 (1) : 24-31. 